\title{
Contraceptive practices among reproductive age group of women in Justice K. S. Hegde Medical College Hospital, Mangalore
}

\author{
Lakshmi Manjeera M*, Neetha, Supriya Rai
}

Department of Obstetrics and Gynecology, K. S. Hegde Medical Academy, NITTE University, Mangalore, India

Received: 7 December 2012

Accepted: 6 January 2013

*Correspondence:

Dr. Lakshmi Manjeera M

E-mail: drmanjeera@yahoo.co.in

\begin{abstract}
Background: India's population as per 2011 census was 1.21 billion second only to china in the world, and is estimated to overtake china by 2050. India was the first country to launch National Family Planning Program in 1952. Even though various measures have been taken to encourage the usage of contraception but, the achievement in this field was not to the extent expected due to various social and cultural factors.

Methods: It was a cross sectional study conducted in out patients and inpatients of department of obstetrics and gynecology, Justice K. S. Hegde medical college hospital, Mangalore. The study constituted 705 subjects. It was an interview based study. The study was aimed to know the awareness, acceptance and prevalence of temporary and permanent contraceptive methods among the study group and various factors affecting the contraceptive usage.

Results: A total of 705 women in the age group between 18-45 years were studied. 671 (95.2\%) were aware of one or multiple methods of contraception, $615(87.2 \%)$ accepted the contraceptive practices, and $495(71.2 \%)$ followed or are following contraception at the time of study. Of 705 women, $366(51.9 \%)$ followed or used temporary methods, $227(32.2 \%)$ followed permanent methods of contraception.

Conclusions: Awareness about the contraception is not sufficient enough to use contraception in the community, also shows that more programs are required to combat the influence of various factors on contraception usage, and emphasizing on the positive effects of the use of contraception.
\end{abstract}

Keywords: Contraception, Temporary and permanent, Awareness, Practices, Population

\section{INTRODUCTION}

India accounts for $2.4 \%$ of the world's surface area yet it supports more than $17.5 \%$ of the world's population. India's population as per 2011 census was 1.21 billion second only to china in the world, and is estimated to overtake china by $2050 .{ }^{1}$ In 1952 , India was the first country to launch family planning program through first five year plan emphasizing family planning (F.P) to the extent necessary for reducing birth rates "to stabilize the population at a level consistent with the requirement of national economy".

The national population policy (NPP) 2000 aims stabilizing the population by 2045 that is by bringing down the total fertility rate (TFR) to 2.1 by 2010 but, the
TFR still continues to be 2.6 and 3 in some states ${ }^{1}$. The London summit on Family planning that took place on 11 July 2012, organized by British department for international development with united nations population fund and other organizations marked the recognition of the key role F.P plays in the development and global health, and the objective being increasing the demand and support for F.P methods and improving supply chains and innovative approach to F.P challenges, with a slogan "Every woman Every child". ${ }^{6}$ Even though many programs are planned and implemented by Government of India and International organizations in the field of F.P with an idea of introducing various family planning methods to the couples in order to avoid unwanted pregnancies, there is development in the acceptance of F.P methods but not to the extent that was targeted, and so the population continues to rise which is a major threat 
to India's health, political, social growth and development. The non acceptance may be due to various reasons like illiteracy, fear of complications, religious beliefs etc. Various studies have been conducted in this field to know the determinants of contraceptive use and causes for non acceptance of contraception, as the acceptance of contraceptives and fertility pattern differs in the societies and the factors responsible for varied picture operate at individual, family and community level (Kansal et al., 2005). ${ }^{6}$ Keeping all these facts in view, this study is planned to know the awareness, acceptance and practices of contraceptive methods in attendees of Obstetrics and Gynecology out-patient department and inpatients of Justice K. S. Hegde Medical College Hospital, Mangalore.

\section{METHODS}

It was a cross sectional study conducted in out-patients and inpatients of department of Obstetrics and Gynecology, Justice K. S. Hegde medical college hospital, Mangalore. Women who were parous in the age group between 18-45 years, constituted the study sample. The study was conducted from February 2012 to august 2012 i.e. for a period of 6 months constituting 705 subjects. An informed consent was taken from the women that were enrolled in the study. It was an interview based study. All the women consented for the study were interviewed based up on a predesigned and pre coded proforma. Women who were infertile and not consented were excluded from the study. Ethical clearance was obtained from institutional committee of the medical college. The study was aimed to know the awareness, acceptance and prevalence of temporary and permanent contraceptive methods among the study group and various factors affecting the contraceptive usage like age, literacy, occupation, socio-economic status, religion and parity were assessed.

Acceptors were those who were willing to follow contraception after explaining and counseling about F.P methods or who have followed or following the contraception. Awareness was those who know about one or multiple methods of contraception. Users of contraception were those who ever used contraception and non users were those who never used contraception till date.

Data analysis was done by SPSS version 20 software. Statistical analysis was done using Pearson chi- square tests, Fisher's exact test and frequency distribution for prevalence analysis.

\section{RESULTS}

A total of 705 women in the age group between 18-45 years were studied. Table 1 shows that $671(95.2 \%)$ were aware of one or multiple methods of contraception, 615 $(87.2 \%)$ accepted the contraceptive practices, and 495
(71.2\%) followed or are following contraception at the time of study (Table 1).

Table 1: Awareness, acceptance and practices of contraceptive methods.

\begin{tabular}{|lll|}
\hline & Yes No.\% & No No. 9\%) \\
\hline Awareness & $671(95.2)$ & $34(4.8)$ \\
\hline Acceptance & $615(87.2)$ & $90(12.8)$ \\
\hline Followed & $495(71.2)$ & $210(29.8)$ \\
\hline
\end{tabular}

Table 2 shows the usage of temporary and permanent methods of contraception. In our study of 705 women, $366(51.9 \%)$ followed or used temporary methods, of which $130(18.4 \%)$ used Intra Uterine Contraceptive Device (IUCD), 110 (15.6\%) used condom, 94 (13.3\%) used rhythm method, $35(05.0 \%)$ used Oral Contraceptive Pills (OCPs), only $1(0.1 \%)$ used inject able methods, and $1(0.1 \%)$ followed emergency contraception. So in our study, the most commonly followed temporary methods were IUCD and condoms. Of 705 women, 227 (32.2\%) followed permanent methods of contraception, of which $224(31.8 \%)$ followed tubectomy and $3(0.4 \%)$ followed vasectomy, so most commonly followed permanent method was female sterilization (Table 2).

Table 2: Users and nonusers of various methods of contraception.

\begin{tabular}{|lll|}
\hline Temporary Method & $\begin{array}{l}\text { Users No. } \\
(\%)\end{array}$ & $\begin{array}{l}\text { Nonusers No. } \\
(\%)\end{array}$ \\
\hline Rhythm & $94(13.3)$ & $611(86.7)$ \\
\hline Condom & $110(15.6)$ & $595(84.4)$ \\
\hline OCP & $35(5.0)$ & $670(95.0)$ \\
\hline IUCD & $130(18.4)$ & $575(81.6)$ \\
\hline Injectables & $01(0.1)$ & $704(99.9)$ \\
\hline Emergency & $01(0.1)$ & $704(99.9)$ \\
\hline Total & $366(51.9)$ & $339(48.1)$ \\
\hline Permanent Method & & \\
\hline Tubectomy & $224(31.8)$ & $481(68.2)$ \\
\hline Vasectomy & $03(0.4)$ & $702(99.6)$ \\
\hline
\end{tabular}

Table 3 shows the demographic profile and contraceptive usage of the 705 women who were studied. A total of 705 women in the age group of 18-45 years were studied, of which majority 391 (55.5\%) women were in the 26-35 years age group, which is the most crucial period in the 
reproductive span, out of which $262(67.0 \%)$ followed contraception. $223(31.6 \%)$ were in $36-45$ years age group, of which $188(84.3 \%)$ followed contraception and $91(12.9 \%)$ were in 18-25 years age group, of which 44 (48.4\%) followed contraception. The contraceptive usage increased as the age increased and this difference was found to be statistically significant. The next parameter studied was women's education status and contraceptive usage, in our study majority of them had primary education that is $297(42.1 \%)$ of which $182(61.3 \%)$ followed contraception. $193(27.4 \%)$ women were metric qualified, of which $142(73.6 \%)$ followed contraception. $91(12.9 \%)$ were intermediate qualified, of which 74 $(81.3 \%)$ followed contraception. 77 (10.9\%) were graduates, of which $64(83.1 \%)$ followed contraception. 5 $(0.7 \%)$ were postgraduates, of which all $5(100.0 \%)$ followed contraception. $42(6.0 \%)$ were illiterates of which $27(64.3 \%)$ followed contraception.

The next studied was husband's education and contraceptive usage, in our study majority of them 313 (44.4\%) had primary education, of which $200(63.9 \%)$ followed contraception.232 (32.9\%) were metric qualified, of which $170(73.3 \%)$ followed contraception. $65(9.2 \%)$ were intermediate qualified, of which 45 (69.2\%) followed contraception.49 (7.0\%) were graduates, of which $43(87.8 \%)$ followed contraception. $15(2.1 \%)$ were postgraduates, of which $13986.7 \%)$ followed contraception. $31(4.4 \%)$ were illiterates, of which $23(74.2 \%)$ followed contraception. As the couple's education increased the contraceptive usage increased which was found to be statistically significant (Table 3).

The next parameter studied was couple's occupation and contraceptive usage. We did not find any influence of occupation on contraception followed.

The next parameter studied was socio economic status and contraceptive usage. In our study the majority 327 (46.4\%) were in Rupees 5001-10,000 income group, of which 227 (69.4\%) followed contraception. 235 (33.3\%) were in Rupees < 5000 income group, of which 150 $(63.8 \%)$ followed contraception. $84(11.9 \%)$ were in Rupees 10,000-20,000 income group, of which 69 $(82.1 \%)$ followed contraception. 59 (8.4\%) were in Rupees > 20,000 income group of which 59 (81.4\%) followed contraception. In our study we found that as the income increased the use of contraception increased and was found to be statistically significant.

The next parameter was Religion and contraceptive usage. In our study, majority 447 (63.4\%) were Hindus, of which $341(76.3 \%)$ followed contraception. 210 (29.8\%) were Muslims, of which 113 (53.8\%) followed contraception. $48(6.8 \%)$ were Christians, of which 40 $(83.3 \%)$ followed contraception. In our study Christians followed contraception the most followed by Hindus and then by Muslims which was statistically significant.
The next parameter was number of living children and contraceptive usage. In our study population, 313 (44.4\%) women had 2 living children, of which 246 (78.6\%) followed contraception. $278(39.4 \%)$ had 1 child, of which $164(59.0 \%)$ followed contraception. 73 $(10.4 \%)$ had 3 children, of which 59 (80.0\%) followed contraception.19 ( $2.7 \%$ ) had 4 children, of which 13 (68.4\%) followed contraception.19 (2.7\%), of which 12 (63.2\%) followed contraception. $3(04 \%)$ had no living children, of which none followed contraception. Higher the number of living children, higher was the usage of contraception which was found to be statistically significant.

Table 4 shows the usage of temporary and permanent methods of contraception and various demographic parameters. In our study of 705 women, in 18-25 years age group $42(46.2 \%)$ followed temporary methods and 5 (5.5\%) followed permanent methods. In 26-35 years age group, $235(60.1 \%)$ followed temporary methods and 77 (19.7\%) followed permanent methods. In 36-45 years age group, 89 (39.9\%) followed temporary methods and 145 $(65.0 \%)$ followed permanent methods. In our study, older the patient higher was the usage of permanent contraception (Table 4).

The next parameter was women's education status, in the category of primary education, $128(43.1 \%)$ followed temporary contraception, and 88 (29.6\%) followed permanent methods. When the women were metric qualified, $107(55.4 \%)$ followed temporary methods and $71(36.8 \%)$ followed permanent methods. When the women were intermediate qualified, 60 (65.9\%) followed temporary methods and $29(31.9 \%)$ followed permanent methods. In the category of graduates, 56 (72.7\%) followed temporary methods and 19 (24.7\%) followed permanent methods. In the category of post graduates, 5 $(100.0 \%)$ followed temporary methods and none followed permanent methods. In the category of illiterates, $10(23.8 \%)$ followed temporary and 20 $(47.6 \%)$ followed permanent methods.

In our study, as the wife's education increased, the usage of temporary methods increased the usage of permanent contraception decreased which was found to be statistically significant.

In the category of husband's education, in our study when the husband had primary education, 133 (42.5\%) followed temporary and $105(33.5 \%)$ followed permanent methods. When they were metric qualified, 139 (59.9\%) followed temporary and $65(28.0 \%)$ followed permanent methods. When they were intermediate educated, 37 (56.9\%) followed temporary and $20(30.8 \%)$ followed permanent methods. In the category of graduates, 39 (79.6\%) followed temporary and $15(30.6 \%)$ followed permanent methods. In the category of postgraduates, 13 $(86.7 \%)$ followed temporary and 1 (6.7\%) followed permanent methods. 
When they were illiterates, $5(16.1 \%)$ followed temporary and $21(67.7 \%)$ followed permanent methods. In our study, there was no significance between husband's education and usage of temporary and permanent methods.

Table 3: Demographic parameter in relation to contraceptive use.

\begin{tabular}{|c|c|c|c|c|c|}
\hline Parameters & $\mathbf{N}$ & $\begin{array}{l}\text { Users } \\
\text { No }(\%)\end{array}$ & $\begin{array}{l}\text { Non Users } \\
\text { No }(\%)\end{array}$ & Chi Square & $p$ Value \\
\hline \multicolumn{6}{|l|}{ Age (Years) } \\
\hline $18-25$ & 91 & $44(48.4)$ & $47(51.6)$ & \multirow{3}{*}{43.763} & \multirow{3}{*}{$<0.001$} \\
\hline $26-35$ & 391 & $262(67.0)$ & $129(33.0)$ & & \\
\hline $36-45$ & 223 & $188(84.3)$ & $35(15.7)$ & & \\
\hline \multicolumn{6}{|l|}{ Wife's Education } \\
\hline Primary & 297 & $182(61.3)$ & $115(38.7)$ & \multirow{6}{*}{26.620} & \multirow{6}{*}{0.001} \\
\hline Matric & 193 & $142(73.6)$ & $51(26.4)$ & & \\
\hline Intermediate & 91 & $74(81.3)$ & 17 (18.7) & & \\
\hline Graduate & 77 & $64(83.1)$ & $13(16.9)$ & & \\
\hline Postgraduate & 05 & $05(100)$ & $00(0.0)$ & & \\
\hline Illiterate & 42 & $27(64.3)$ & $15(35.7)$ & & \\
\hline \multicolumn{6}{|c|}{ Husband's Education } \\
\hline Primary & 313 & $200(63.9)$ & $113(36.1)$ & \multirow{6}{*}{16.374} & \multirow{6}{*}{$<0.006$} \\
\hline Matric & 232 & $170(73.3)$ & $62(26.7)$ & & \\
\hline Intermediate & 65 & $45(69.2)$ & $20(30.8)$ & & \\
\hline Graduate & 49 & $43(87.8)$ & $06(12.2)$ & & \\
\hline Postgraduate & 15 & $13(86.7)$ & $02(13.3)$ & & \\
\hline Illiterate & 31 & $23(74.2)$ & $08(25.8)$ & & \\
\hline \multicolumn{6}{|l|}{ Wife's Occupation } \\
\hline Professional & 13 & $12(92.3)$ & $01(07.7)$ & \multirow{3}{*}{3.13} & \multirow{3}{*}{0.209} \\
\hline Non-Professional & 226 & $158(69.9)$ & $68(30.1)$ & & \\
\hline Housewife & 466 & $324(69.5)$ & $142(30.5)$ & & \\
\hline \multicolumn{6}{|c|}{ Husband's Occupation } \\
\hline Professional & 10 & $09(90.0)$ & $01(10.0)$ & \multirow{3}{*}{2.199} & \multirow{3}{*}{0.333} \\
\hline Non-Professional & 686 & $478(69.7)$ & $208(30.3)$ & & \\
\hline Unemployed & 09 & $07(77.8)$ & $02(22.2)$ & & \\
\hline \multicolumn{6}{|c|}{ Socio-Economic Status } \\
\hline$<5000$ & 235 & $150(63.8)$ & $85(36.2)$ & \multirow{4}{*}{13.851} & \multirow{4}{*}{0.003} \\
\hline $5001-10000$ & 327 & $227(69.4)$ & $100(30.6)$ & & \\
\hline $10001-20000$ & 84 & $69(82.1)$ & $15(17.9)$ & & \\
\hline$>20000$ & 59 & $48(81.4)$ & $11(18.6)$ & & \\
\hline \multicolumn{6}{|l|}{ Religion } \\
\hline Hindu & 447 & $341(76.3)$ & $106(23.7)$ & \multirow{3}{*}{38.739} & \multirow{3}{*}{$<0.001$} \\
\hline Muslim & 210 & $113(53.8)$ & $97(46.2)$ & & \\
\hline Christian & 48 & $40(83.3)$ & 08 (16.7) & & \\
\hline \multicolumn{6}{|c|}{ No. of Living Children } \\
\hline
\end{tabular}




\begin{tabular}{|c|c|c|c|c|c|}
\hline 0 & 03 & $00(0.0)$ & 03 (100.0) & \multirow{6}{*}{38.616} & \multirow{6}{*}{0.000} \\
\hline 1 & 278 & $164(59.0)$ & $114(41.0)$ & & \\
\hline 2 & 313 & 246 (78.6) & $67(21.4)$ & & \\
\hline 3 & 73 & $59(80.0)$ & $14(19.2)$ & & \\
\hline 4 & 19 & $13(68.4)$ & $06(31.6)$ & & \\
\hline $5 \&$ More & 19 & $12(63.2)$ & $07(36.8)$ & & \\
\hline
\end{tabular}

Table 4: Demographic parameters in relation to temporary \& permanent contraceptive use.

\begin{tabular}{|c|c|c|c|c|c|c|c|c|}
\hline Parameters & Temporary & & $\begin{array}{l}\text { Chi } \\
\text { Square }\end{array}$ & $p$ Value & Permanent & & $\begin{array}{l}\text { Chi } \\
\text { Square }\end{array}$ & $p$ Value \\
\hline & $\begin{array}{l}\text { Users } \\
\text { No. }(\%)\end{array}$ & $\begin{array}{l}\text { Non Users } \\
\text { No. }(\%)\end{array}$ & & & $\begin{array}{l}\text { Users } \\
\text { No. }(\%)\end{array}$ & $\begin{array}{l}\text { Non Users } \\
\text { No. }(\%)\end{array}$ & & \\
\hline \multicolumn{9}{|l|}{ Age (Years) } \\
\hline $\begin{array}{l}18-25 \\
26-35 \\
36-45\end{array}$ & $\begin{array}{l}42(46.2) \\
235(60.1) \\
89(39.9)\end{array}$ & $\begin{array}{l}49(53.8) \\
156(39.9) \\
134(60.1)\end{array}$ & 24.583 & $<0.001$ & $\begin{array}{l}05(5.5) \\
77(19.7) \\
145(65.0)\end{array}$ & $\begin{array}{l}86(94.5) \\
314(80.3) \\
78(35.0)\end{array}$ & 167.789 & $<0.001$ \\
\hline \multicolumn{9}{|l|}{ Wife's Education } \\
\hline $\begin{array}{l}\text { Primary } \\
\text { Matric } \\
\text { Intermediate } \\
\text { Graduate } \\
\text { Post -Graduate } \\
\text { Illiterate }\end{array}$ & $\begin{array}{l}128(43.1) \\
107(55.4) \\
60(65.9) \\
56(72.7) \\
05(100.0) \\
10(23.8)\end{array}$ & $\begin{array}{l}169(56.9) \\
86(44.9) \\
31(34.1) \\
21(27.3) \\
00(0.0) \\
32(76.2)\end{array}$ & 48.657 & $<0.001$ & $\begin{array}{l}88(29.6) \\
71(36.8) \\
29(31.9) \\
19(24.7) \\
00(0.0) \\
20(47.6)\end{array}$ & $\begin{array}{l}209(70.4) \\
122(63.2) \\
62(68.1) \\
58(75.3) \\
05(100.0) \\
22(52.4)\end{array}$ & 11.710 & 0.039 \\
\hline \multicolumn{9}{|l|}{$\begin{array}{l}\text { Husband's } \\
\text { Education }\end{array}$} \\
\hline $\begin{array}{l}\text { Primary } \\
\text { Matric } \\
\text { Intermediate } \\
\text { Graduate } \\
\text { Post- Graduate } \\
\text { Illiterate }\end{array}$ & $\begin{array}{l}133(42.5) \\
139(59.9) \\
37(56.9) \\
39(79.6) \\
13(86.7) \\
05(16.1)\end{array}$ & $\begin{array}{l}180(57.5) \\
93(40.1) \\
28(43.1) \\
10(20.4) \\
02(13.3) \\
26(83.9)\end{array}$ & 55.928 & $<0.001$ & $\begin{array}{l}105(33.5) \\
65(28.0) \\
20(30.8) \\
15(30.6) \\
01(6.7) \\
21(67.7)\end{array}$ & $\begin{array}{l}208(66.5) \\
167(72.0) \\
45(69.2) \\
34(69.4) \\
14(93.3) \\
10(32.3)\end{array}$ & 24.654 & $<0.001$ \\
\hline \multicolumn{9}{|l|}{$\begin{array}{l}\text { Wife's } \\
\text { Occupation }\end{array}$} \\
\hline $\begin{array}{l}\text { Professional } \\
\text { Non Professional } \\
\text { Housewife }\end{array}$ & $\begin{array}{l}10(76.9) \\
124(54.9) \\
232(49.8)\end{array}$ & $\begin{array}{l}03(23.1) \\
102(45.1) \\
234(50.2)\end{array}$ & 4.893 & 0.087 & $\begin{array}{l}03(23.1) \\
63(27.9) \\
161(34.5)\end{array}$ & $\begin{array}{l}10(76.9) \\
163(72.1) \\
305(65.5)\end{array}$ & 3.609 & 0.165 \\
\hline \multicolumn{9}{|l|}{$\begin{array}{l}\text { Husband's } \\
\text { Occupation }\end{array}$} \\
\hline $\begin{array}{l}\text { Professional } \\
\text { Non Professional } \\
\text { Unemployed }\end{array}$ & $\begin{array}{l}07(70.0) \\
354(51.6) \\
05(55.6)\end{array}$ & $\begin{array}{l}03(30.0) \\
332(48.4) \\
04(44.4)\end{array}$ & 1.385 & 0.500 & $\begin{array}{l}02(20.0) \\
221(32.2) \\
04(44.4)\end{array}$ & $\begin{array}{l}08(80.0) \\
465(67.8) \\
05(55.6)\end{array}$ & 1.300 & 0.522 \\
\hline $\begin{array}{l}\text { Socio Economic } \\
\text { Status }\end{array}$ & & & & & & & & \\
\hline
\end{tabular}




\begin{tabular}{|c|c|c|c|c|c|c|c|c|}
\hline $\begin{array}{l}<5000 \\
5001-10,000 \\
10,001-20,000 \\
>20,000\end{array}$ & $\begin{array}{l}94(40.0) \\
178(54.4) \\
55(65.5) \\
39(66.1)\end{array}$ & $\begin{array}{l}141(60.0) \\
149(45.6) \\
29(34.5) \\
20(33.9)\end{array}$ & 25.141 & $<0.001$ & $\begin{array}{l}82(34.9) \\
94(28.7) \\
35(41.7) \\
16(27.1)\end{array}$ & $\begin{array}{l}153(65.1) \\
233(71.3) \\
49(58.3) \\
43(72.9)\end{array}$ & 6.714 & 0.082 \\
\hline \multicolumn{9}{|l|}{ Religion } \\
\hline $\begin{array}{l}\text { Hindus } \\
\text { Muslims } \\
\text { Christians }\end{array}$ & $\begin{array}{l}251(56.2) \\
88(41.9) \\
27(56.2)\end{array}$ & $\begin{array}{l}196(43.8) \\
122(58.1) \\
21(43.8)\end{array}$ & 12.006 & 0.002 & $\begin{array}{l}164(36.7) \\
41(19.5) \\
22(45.8)\end{array}$ & $\begin{array}{l}283(63.3) \\
169(80.5) \\
26(54.2)\end{array}$ & 23.670 & $<0.001$ \\
\hline \multicolumn{9}{|l|}{$\begin{array}{l}\text { Number Of } \\
\text { Living Children }\end{array}$} \\
\hline $\begin{array}{l}0 \\
1 \\
2 \\
3 \\
4 \\
5\end{array}$ & $\begin{array}{l}00(0.0) \\
163(58.6) \\
162(51.8) \\
29(39.7) \\
04(21.1) \\
08(42.1)\end{array}$ & $\begin{array}{l}3(100.0) \\
115(41.4) \\
151(48.2) \\
44(60.3) \\
15(78.9) \\
11(57.9)\end{array}$ & 20.595 & 0.001 & $\begin{array}{l}00(0.0) \\
05(1.8) \\
158(50.5) \\
46(63.0) \\
10(52.6) \\
08(42.1)\end{array}$ & $\begin{array}{l}03(100.0) \\
273(98.2) \\
155(49.5) \\
27(37.0) \\
09(47.4) \\
11(57.9)\end{array}$ & 203.262 & $<0.001$ \\
\hline
\end{tabular}

The next parameter assessed was couple's occupation. No statistical significance was found between couple's occupation and temporary and permanent methods usage. The next parameter studied was socioeconomic status, in our study in Rupees $<5000$ category, 94 (40.0\%) followed temporary and $82(34.9 \%)$ followed permanent methods. In category of Rupees 5001-10,000 category, $178(54.4 \%)$ followed temporary and $94(28.7 \%)$ followed permanent, In Rupees 10,001-20,000 category, $55(65.5 \%)$ followed temporary and $35(41.7 \%)$ followed permanent methods. In Rupees >20,000 category, 39 $(66.1 \%)$ followed temporary and $16(27.1 \%)$ followed permanent methods. In our study, as the income increased the usage of temporary contraception increased which was statistically significant but no significant change is seen in the usage of permanent methods.

The next parameter assessed was religion, in our study, in Hindus 251 (56.2\%) followed temporary and 164 $(36.7 \%)$ followed permanent methods. In Muslims, 88 $(41.9 \%)$ followed temporary and $41(19.5 \%)$ followed permanent methods. In Christians, 27 (56.2\%) followed temporary and $22(45.8 \%)$ followed permanent methods. In our study, we found that Muslims followed the temporary methods the least. Permanent methods were followed mainly by Christians, which was found to be statistically significant.

The next parameter assessed was number of living children and contraception usage, in our study, none followed the contraception if women had no living children. When they had 1 living child, 163 (58.6\%) followed temporary and $5(1.8 \%)$ followed permanent methods. When they had 2 living children, $162(51.8 \%)$ followed temporary and $158(50.5 \%)$ followed permanent methods. When they had 3 living children, 29 (39.7\%) followed temporary and $46(63.0 \%)$ followed permanent methods. When they had 4 living children, 4 (21.1\%) followed temporary and $10(52.6 \%)$ followed permanent methods. When they had 5 or more children, $8(42.1 \%)$ followed temporary and $8(42.1 \%)$ followed permanent methods. In our study, we found that temporary methods were followed highest by women with 1 living child and permanent methods were followed highest when women had 2 living children which was statistically significant.

The pie diagram depicts the various reasons for not using contraception (Figure 1). Out of 210 women who have not followed any sort of contraception, the reasons given were, majority $58(27.61 \%)$ wanted more children, 34 $(16.1 \%)$ for fear of complications, $43(20.47 \%)$ were staying apart, $29(13.80 \%)$ for religious beliefs, 17 $(8.09 \%)$ for husband's/family opposition, 13 (6.19\%) for ignorance of practices, $10(04.76 \%)$ for infrequent sex and $8(3.80 \%)$ for not having sex.

\section{DISCUSSION}

Family planning basically refers to the practices that help the individuals or couples to avoid unwanted births, to regulate the interval between pregnancies, controls the time at which birth occurs in relation to the age of parents and determines the number of children in the family. ${ }^{18}$ In the present study, 95.2\% were aware of one or multiple methods of contraception, which is almost similar to prevalence of knowledge $97.7 \%$ reported by National family health survey (NFHS) $-3^{3}$, slightly less than Takkar et al where they reported $100 \%$ in their study ${ }^{20}$ more than the incidence reported by Sajid A et $\mathrm{al}^{19}$ study done in Pakistan where awareness was $60 \%$. The acceptance of contraception was $87.2 \%$ following counseling. $71.2 \%$ followed or are following one or multiple methods of contraception higher than NFHS-3 (2005-06) where overall contraceptive usage in Karnataka was $63.6 \%$, and $61.8 \%^{19}$ as per DLHS (District level health survey) Karnataka ,68.4\%, 59.92\%, 59.2\% ,34.92\%, as reported by Kiran G. Makade et $\mathrm{al}^{16}$, Padmaja Ravindra Walvekar et $\mathrm{al}^{7}$, Neelu Saluja et al ${ }^{12}$ DR Gaur et al. ${ }^{9}$ 
In our study, it was observed that majority of the study women $51.9 \%$ followed temporary methods and $32.2 \%$ followed permanent methods which correlates to the study done by DR Gaur et $\mathrm{al}^{9} \mathrm{~S}$. Giridhar et al where they observed $61 \%$ and $39 \%$ and $49.5 \%$ and $37.6 \%$ temporary and permanent respectively. In contrast the study done by Neelu Saluja et $\mathrm{al}^{2}$, Kumari $\mathrm{C}^{14}$, the majority of them $46.0 \%$ followed permanent methods which is higher when compared to our study. Of temporary methods followed IUCD being commonest temporary method which correlates to the study done by Chopra S Dhaliwal et $\mathrm{al}^{11}$, DR Gaur et $\mathrm{al}^{9}$ and female sterilization being the most common permanent method followed which corresponds to study done by DR Gaur et al. ${ }^{9}$ Women in the younger age group of 18-25 years, followed temporary methods and women in later age group of 3645 years preferred permanent method; the reason was obvious as they would have completed the family. Similar findings were reported by S. Giridhar et al in her study in rural areas of Punjab ${ }^{8}$ and by DR Gaur et al in a study in rural area of Mewat. ${ }^{9}$

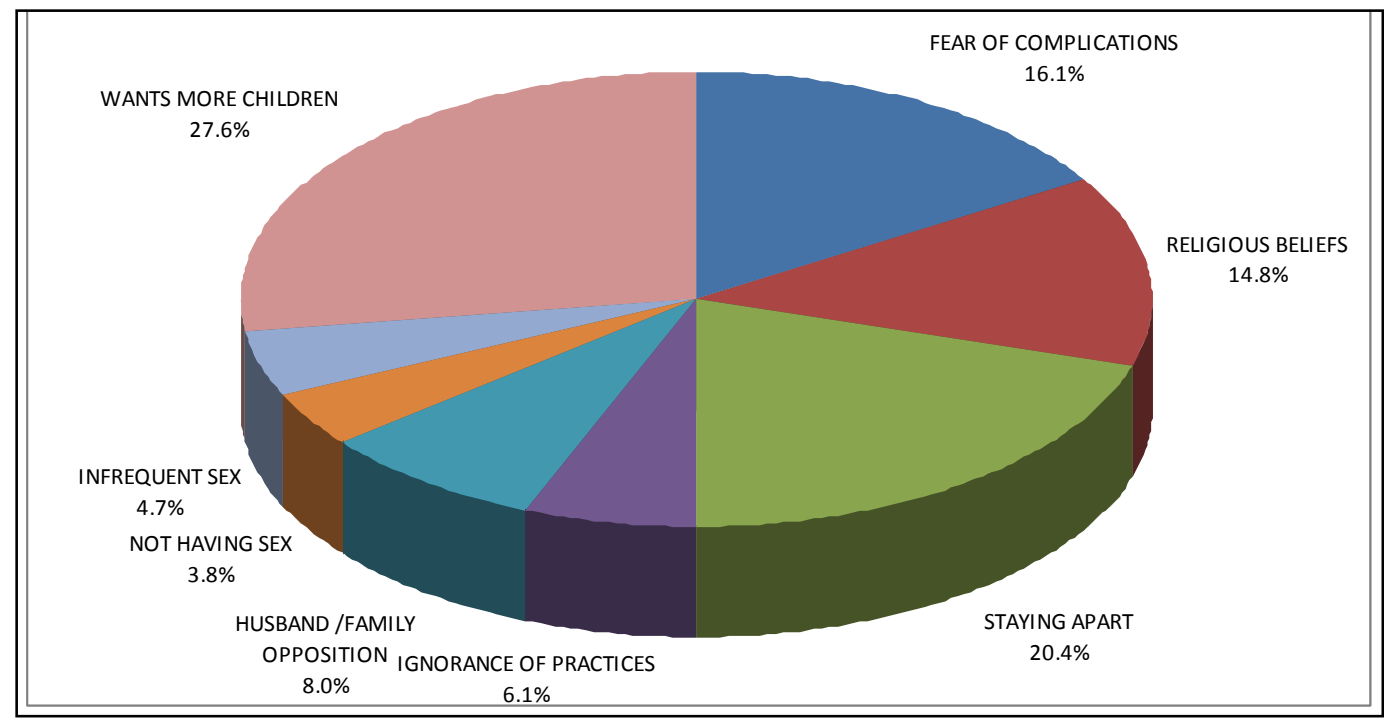

Figure 1: Reasons for not using contraception.

In this study, it was observed that literacy influenced the contraceptive usage, higher the education status of the couple, higher was the contraceptive usage, and similar findings were reported by S. Giridhar et al in their study. ${ }^{8}$ Contrary to our findings, study done by Padmaja Ravindra Walvekar in Belgaum, Karnataka did not find any influence of literacy on contraceptive usage. ${ }^{7}$

Couple's occupation had no influence in following contraception. Study done by Pushpa et al reported that acceptance was high in employed group. ${ }^{10}$

In our study higher the socio economic status, higher was the usage of temporary methods which was statistically significant $(p<0.001)$ but no significant change was observed in the usage of permanent methods, Bhattacharya $\mathrm{M}^{13}$ in his study found that higher income women were more likely to use permanent methods.

In our study, we found an association between religion and contraceptive usage. In our study Christians followed the most then the Hindus and Muslims followed the least which was statistically significant $(p<0.002)$. Permanent methods were opted majority by the Christians (45.8\%), then Hindus (36.7\%) and Muslims (19.5\%) followed the least which was found to be statistically significant
( $p<0.001)$, similar findings were reported in a study done by DR Gaur et al Rural area of Mewat, Rohtak, India9, Mohanan $\mathrm{P}$ et $\mathrm{al}^{15}$ in their study done in Asaigoli $20 \mathrm{~km}$ from Mangalore found that muslims followed permanent methods the least. SP Puspha et al in her study did not find any influence of religion on contraceptive usage. ${ }^{10}$

In our study, more the number of living children, higher was the usage of contraception. Women with 2 and 3 children opted for permanent methods when compared to women with 1 child, who followed temporary methods the reason being obvious and was found to be statistically significant $(p<0.001)$ which is similar to study reported by SP Pushpa et $\mathrm{al}^{10}$ and S Giridhar et $\mathrm{al}^{8}$ Mohanan P et al. $^{15}$

In our study $29.8 \%$ were non users. Reasons for not using contraception, the most common were, the couple wants to have more children, staying apart, religious beliefs ,husband's or family opposition etc, which correlates to the study reported by Neelu Saluja et al ${ }^{12}$ Sajid A et al. ${ }^{18}$ 


\section{CONCLUSIONS}

These results clearly indicate that awareness about the contraception is not sufficient enough to use contraception in the community, extended efforts are required to make them understand the importance and to follow the contraception. ${ }^{16}$ The present study shows that more programs are required to combat the influence of various factors on contraception usage, and emphasizing on the positive effects of the use of contraception and misconceptions regarding the ill effects of the family planning methods.

\section{ACKNOWLEDGEMENTS}

We are thankful to all the patients who co-operated for this study and for all the staff and post- graduate students who helped us in collecting the data.

Funding: No funding sources

Competing interests: There are no competing interests to declare

Ethical approval: The study was approved by the Institutional ethics committee

\section{REFERENCES}

1. Government of India. National population policy2000. Available at http://planningcomission.nic.in. Accessed 5 December 2012.

2. Population stabilization- The way ahead: World population day July 11 2011. Available at http://www.indiacsr.in. Accessed 15 October 2012.

3. National family health survey (NFHS-3) 2005-2006. Available at http://www.rchips.org. Accessed 5 December 2012.

4. Kansal RC, Kandapal SD, Negi KS. Epidemiological correlates of contraceptive prevalence in rural population of Dehradun district. IJCM 2005;30:60-2.

5. Park K. Demography and Family planning. In: Park's Textbook of preventive and social medicine, 18th ed. M/s Banarasidas Bhanot Publishers, Jabalpur, India; 2007:443-56.

6. Women at the centre of the London summit on Family planning. July 2012. Available at http://www.un-ngls.org. Accessed 15 October 2012.

7. Walvekar PR. Determinants of contraceptive use among married women residing in rural areas of Belgaum. J Med Allied Sciences 2012;2:7-11.
8. Giridhar S, Chaudhary A, Gill P, Soni RK, Sachar R. Contraceptive practices and related factors among married women in a rural area of Ludhiana. Internet J Health 2010;12[1].

9. Gaur DR, Goel MK, Goel M. Contraceptive practices and related factors among females in predominantly Muslim area of North India. Internet J World Health Societal Politics. 2008;5[1].

10. Pushpa SP, Venkatesh R, Shivaswamy MS. Study of fertility pattern and contraceptive practices in a rural area- a cross sectional study. Indian J Sci Technol 2011;4:429-31.

11. Chopra S, Dhaliwal L Knowledge Attitude and Practices of contraception in Urban population of North India. Arch Gynaecol Obstet 2010;281:273-7.

12. Saluja N, Sharma S, Choudhary S, Gaur DR. Contraceptive knowledge, Attitude and Practices Among Eligible Couples of Rural Haryana. Internet J Health 2011;12:[1].

13. Bhattacharya M, Joshi PL, Raj B. Socio Economic correlates of fertility and contraceptive practices amongst target couples of a rural community. Indian J Public Health 1984;28:139-46.

14. Kumari C. Contraceptive practices of women living in rural areas of Bihar. Br J Fam Plann 1998;24:757.

15. Mohanan P, Asha K, Sajjan BS. Fertility pattern and Family Planning Practices in a rural area in Dakshina Kannada. IJCM 2003;26:15-8.

16. Makade KG, Padhyagurjar M, Padhyegurjar SB, Kulkarni RN. Study of Contraceptive use among married women in a slum in Mumbai. Nat $\mathbf{J}$ Comm Med 2012;3:40-3.

17. Sajid A, Malik S. Knowledge Attitude and Practice of contraception among multiparous women at Lady Aitchison hospital, Lahore. Annals of KEMU. 2010;16:266-8.

18. Deb R. Knowledge, Attitude and Practices related to Family planning methods among the khasi Tribes of East Khasi hills Meghalaya. Anthropologist 2010;12:41-5.

19. DLHS-3 2007-2008. Fact sheet Karnataka. Available at http://www.jskgov.in. Accessed 5 December 2012.

20. Takkar N, Goel P, Dua D. Contraceptive practices and awareness of emergency contraception in educated working women. Indian $\mathrm{J}$ Med Sci 2005;59:143-9.

DOI: $10.5455 / 2320-1770 . i j r \operatorname{cog} 20130207$

Cite this article as: Lakshmi MM, Neetha, Rai S. Contraceptive practices among reproductive age group of women in Justice K. S. Hegde Medical College Hospital, Mangalore. Int J Reprod Contracept Obstet Gynecol 2013;2:39-46. 